\title{
Central and Eastern Europe Civic Education Project
}

\author{
Jonathan Stein, Yale University
}

\begin{abstract}
Recent changes in Eastern Europe and the Soviet Union have been rapidly transforming social and political institutions, and, of course, attracting scholarly attention from a wide variety of disciplines in the West. So far, however, there have been few formal, ongoing programs established to meet the needs of curriculum reform in undergraduate education and professional development of faculties within these countries' own universities. Disciplines which were especially neglected or distorted by Communist Party control over higher education include most of those in the social sciences.

Starting this year, that too will begin to change. This September, the
\end{abstract} Civic Education Project, a program based at Yale University, will send thirteen graduate students and two professors to teach sociology, political science, international relations, and economics at eight universities in Czechoslovakia. The program, which is receiving funding for its first year from the Charter 77 FoundationNew York and the Central European University-Prague, is planning to expand in coming years to universities in Hungary, Poland, Rumania, Bulgaria, and perhaps several republics in what is now still the Soviet Union. Plans are also under way to recruit instructors to teach more students.

One of the more remarkable features of the program is that it was conceived, founded, and is administered entirely by graduate students. It is the brainchild of Steve Grand, a doctoral candidate in Harvard University's Government Department. Grand, who has been living in Prague while doing research on wage policy in the transition to capitalism, has received enthusiastic support from administrators at local universities. These include Charles University, the Prague Higher School of Economics, the Bratislava School of Economics, Commenius University, Silesia University, the University of Agriculture at Nitra, and Palacky
University. Each will provide stipends and housing, and instructors will be regarded as faculty members.

While a few professors will be hired each year, the bulk of the teaching will continue to be done by advanced graduate students and recent graduates of professional schools of international affairs. "The advantages of hiring graduate students are fairly obvious," explained Bill Antholis, the program's U.S. coordinator and a doctoral candidate in Yale's Political Science Department. "Graduate students are highly motivated people who usually don't have mortgages and family commitments. This means that a program like this one can be run on a relatively small budget." It also means that the Civic Education Project is assured of attracting a large applicant pool from which to select the most qualified applicants. This year's instructors were picked from sixtyfive who applied, and Antholis expects that with increased publicity next year's pool will number three to four hundred.

Grand, who will remain in Prague this year to oversee the expansion efforts, envisions a program that combines aspects of the Peace Corps and the Fulbright program. "If the process of reform is to succeed," he argues, "it is absolutely essential that universities train students not only in the technical disciplines, but also in western approaches to the social sciences." It is just as important, however, that young western scholars "attain a level of usable knowledge in Eastern European affairs that can best be achieved through hands-on experience." The teaching program will therefore be augmented by a series of regularly scheduled meetings, seminars, and opportunities for instructors to present research.

Excitement about the Civic Education Project is shared by Yale history professor Gaddis Smith, the program's faculty advisor. "We are at one of those extraordinary turning points in world history," Smith said.
"It's very important that the personal and intellectual connections are made at this stage, and both for our sake and theirs it's a good thing that the initiative has been taken by young people."

Both Grand and Antholis are sensitive to concerns that the Civic Education Project might be subject to the same kind of criticism often leveled against programs like the Peace Corps. "It is not our purpose to replace one orthodoxy with another," says Grand. "The most important lesson we want to impart is that there can be and should be genuine pluralism in the research agendas and methods of the social sciences."

Antholis concurs and testifies to the varied interests of this year's instructors. "There was no ideological litmus test in our selection process, and we're very proud of the fact that our instructors range from democratic socialists to staunch proponents of free market capitalism. The West has produced a broad array of political positions and possibilities, and that will continue to be reflected in the groups that we send. After all," he adds with a laugh, "it's the fundamental chaos of these debates that makes the social sciences so much fun."

\footnotetext{
About the Author

Jonathan Stein, a doctoral candidate in Yale's Political Science Department, is Coordinating Instructor for the Civic Education Project.
} 